\title{
Application of the AIDS model in hass avocado consumption in Mexico
}

\section{Aplicación del modelo AIDS en el consumo de aguacate hass en México}

\author{
GÓMEZ-GÓMEZ, Alma Alicia†**, LUQUEZ-GAITAN, Carlos Ernesto and LÓPEZ-VELÁZQUEZ, \\ Lessly Gabriela
}

ID $1^{\text {st }}$ Author: Alma Alicia, Gómez-Gómez / ORC ID: 0000-0002-7820-6629, CVU CONACYT ID: 15624

ID $1^{\text {st }}$ Co-author: Carlos Ernesto, Luquez-Gaitan / ORC ID: 0000-0002-2863-0851, CVU CONACYT ID: 631756

ID $2^{\text {nd }}$ Co-author: Lessly Gabriela, López-Velázquez / ORC ID: 0000-0003-0062-8810

DOI: $10.35429 /$ JM.2020.6.4.24.30

Received January 20, 2020; Accepted June 2020, 2020

\begin{abstract}
Avocado is a product of national importance because it is exported, but part of its production is dedicated to national consumption, in this study the behavior of the demand for this product at the national level was analyzed, involving seven additional products that were: corn, green chili, tomato, lemon, beef, pork and chicken; For the study, the model of the almost ideal demand system (AIDS) was used and the method of apparently unrelated equations (SUR) was used with the support of the SUR / SYSNLIN function of the SAS system; The Marshallian, Hicksian and Expenditure elasticities were obtained for monthly consumption from 2004 to 2015 reported in the agricultural and fishing information system (SIAP), it was concluded that avocado has a normal inelastic demand with respect to expenditure, in addition to being a good substitute for corn, green chili, lemon, beef and chicken; and complementary to tomato and pork.
\end{abstract}

Substitute goods, Complementary goods, Marshallian elasticity, Hicksian elasticity, SUR funct

\section{Resumen}

El aguacate es un producto de importancia nacional debido a que se exporta, pero parte de su producción se dedica al consumo nacional, en este estudio se analizó el comportamiento de la demanda de este producto a nivel nacional, involucrando a siete productos adicionales que fueron: maíz, chile verde, jitomate, limón, carne de res, cerdo y pollo; para el estudio se usó el modelo del sistema de demanda casi ideal (AIDS) y se empleó el método de ecuaciones aparentemente no relacionadas (SUR) con apoyo de la función SUR/SYSNLIN del sistema SAS; se obtuvieron las elasticidades Marshallianas, Hicksianas y de Gasto para el consumo mensual de 2004 a 2015 reportado en el sistema de información agropecuaria y pesca (SIAP), se concluyó que el aguacate tiene una demanda inelástica normal respecto al gasto, además de ser un bien sustituto del maíz, chile verde, limón, carnes de res y pollo; y complementario del jitomate y la carne de cerdo.

Bienes sustitutos, Bienes complementarios, Elasticidad Marshalliana, Elasticidad Hicksiana, Función SUR

Citation: GÓMEZ-GÓMEZ, Alma Alicia, LUQUEZ-GAITAN, Carlos Ernesto and LÓPEZ-VELÁZQUEZ, Lessly Gabriela. Application of the AIDS model in hass avocado consumption in Mexico. RINOE Journal-Microeconomics. 2020. 4-6:24-30.

$\uparrow$ Researcher contributing first author. 


\section{Introduction}

The avocado (Persea americana) is native to Mesoamerica, where there are approximately 90 species of this genus distributed from central Mexico to Central America. The avocado is of great economic importance in Mexico, being the main producer and exporter worldwide, more than $50 \%$ of the production is destined to this sector, mainly for the United States and Canada. In total, the country has approximately a planted area of 150 thousand hectares of avocado and an approximate production of 1.5 million tons per year (FND, 2014).

In this study, the almost ideal demand model (AIDS) was applied to avocado consumption in Mexico to know the behavior before the consumption of corn, lemon, green chili, tomato, pork, beef and chicken.

The objective of the research is to estimate an AIDS system with eight elements of the basic basket to analyze the behavior of the demand for avocado in Mexico.

This work seeks to verify the following hypotheses: Avocado is a product with inelastic national demand. Avocado is a product with normal national spending demand. Avocado is a complementary product to corn, green chili, tomato, lemon, beef, pork and chicken.

\section{Materials and methods}

\section{Applications of the Near Ideal Demand System (AIDS)}

The AIDS model was developed in 1980 by Deaton and Muellbauer, it was derived under the assumption of separability. This model derives from the expenditure function that represents an order of preferences, expenditure is minimized with the restriction of a fixed utility level. This model allows corresponding theoretical restrictions to be imposed and verified (Fernández, 2007). The AIDS model was designed for application in the analysis of the demand for goods such as food, clothing and housing, it has been adapted to the study of demand for differentiated products (Arellano, 2015).

The Almost Ideal Demand System (AIDS) model is a system of equations defined as follows (Deaton \& Muellebauer, 1996):

$$
w_{i t}=\alpha_{i}+\sum_{j=1}^{m} \gamma_{i j} \log \left(p_{i t}\right)+\beta_{i} \log \left(X_{t} / P_{t}^{S}\right)+\varepsilon_{i j}
$$

Where:

$w_{i t} \rightarrow$ It is the participation of the $\mathrm{i}$-th good in the total expenditure of the group of goods considered, defined as:

$w_{i t}=Q_{i t} p_{i} / \sum_{j=1}^{m} Q_{j t} p_{j t}$

$Q_{i t} \rightarrow$ It is the consumed quantity of the i-th good.

$p_{i t} \rightarrow$ It is the price of the i-th good.

$\alpha_{i} \rightarrow$ It is the regression estimator of the ordinate to the origin.

$\beta_{i} \rightarrow$ It is the regression estimator of the budget relation and the price index of the i-th good.

$\gamma_{i j} \rightarrow$ It is the price regression estimator of the $\mathrm{i}$-th good with respect to that of the $\mathrm{j}$-th good.

$P_{t}^{S} \rightarrow$ It is the Stone Price Index, defined by its logarithm:

$\log \left(P_{t}^{S}\right)=\sum_{i=1}^{n} w_{i t} \log \left(p_{i t}\right)$

$X_{t} \rightarrow$ It is the total expenditure of the goods considered, defined as:

$X_{t}=\sum_{j=1}^{m} Q_{j t} p_{j}$

$t \rightarrow$ It is the evaluated period.

$i \quad \rightarrow$ It is the good considered, from the first to the n-th good.

$j \quad \rightarrow \quad$ It is the good considered, from the first to the m-th good.

$\varepsilon_{i j} \rightarrow$ It is the estimation error.

For the present work, the Stone Price Index $\left(\mathrm{P}_{-} \mathrm{t} \wedge \mathrm{S}\right)$ was used, defined by its aforementioned logarithm. This is due to the fact that in different previous works such as those of Martínez-Damián et al. (2016), González (2013), Pastor and Gómez (2018) and Kido-Cruz \& Kido-Cruz (2013), to mention some examples where the AIDS model has been used, this price index has been used following the approach of Deaton \& Muellebauer's solution, (1996), to facilitate the calculation, since the use of another index implies using non-linear models.

GÓMEZ-GÓMEZ, Alma Alicia, LUQUEZ-GAITAN, Carlos Ernesto and LÓPEZ-VELÁZQUEZ, Lessly Gabriela. Application of the AIDS model in hass avocado consumption in Mexico. RINOE Journal-Microeconomics. 2020 
The system of equations has certain restrictions or conditions suggested by the demand theory that are introduced into the process of estimating parameters, which must meet the following:

1. Aggregation:

$$
\sum_{i=1}^{n} \alpha_{i}=1, \quad \sum_{i=1}^{n} \gamma_{i j}=\sum_{i=1}^{n} \beta_{i}=0
$$

2. Homogeneity:

$$
\sum_{j=1}^{m} \gamma_{i j}=0
$$

3. Symmetry:

$$
\gamma_{i j}=\gamma_{j i}
$$

\section{Information used}

In order to develop the AIDS model, monthly consumption data for each of the i-th goods considered were obtained from the Agrifood and Fisheries Information Service (SIAP), consulted online at www.gob.mx/siap, considering the following goods:

- Avocado.

- $\quad$ Green chile.

- Tomato.

- Corn.

- Lemon.

- $\quad$ Pork Meat.

- $\quad$ Chicken meat.

$-\quad$ Beef.

For which the following were consulted: prices $(M X N / t)$, production $(t)$, exports $(t)$ and imports (t) in order to obtain apparent consumption using the following formula:

Apparent Consumption $(\mathrm{Q})=$ Production (Y) + Imports (I) - Exports (E)

\section{Results and Discussion}

The average consumption of the selected basic basket of eight products amounts to just over 3.35 million tons per month, representing just over 55 billion pesos, where the product with the highest proportion of budget allocation is corn, followed by meats chicken and beef, as can be seen in table 1.

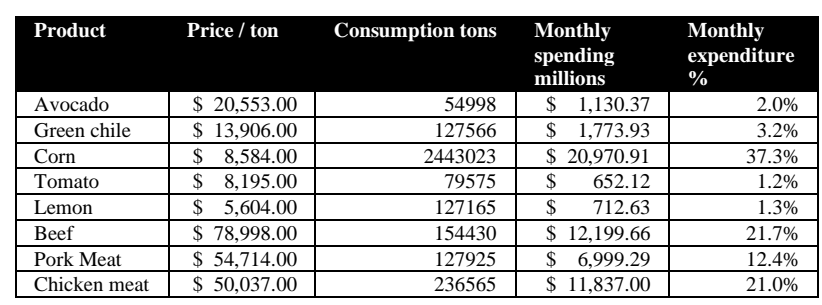

Table 1 Summary of Average Monthly Spending for families from 2014-2015

Source: SIAP, 2018

Avocado represents just $1.9 \%$ of the monthly expenditure for the consumption of this product, being the third smallest, and the sixth in order of budget allocation, just below corn and meat, as can be seen in Graphic 1.

However, consumption in tons of avocado barely covers $1.6 \%$, while that of corn is $72.9 \%$, which is fully consistent with the Mexican diet, which has a strong base in this good, as observed in the Graphic 2.

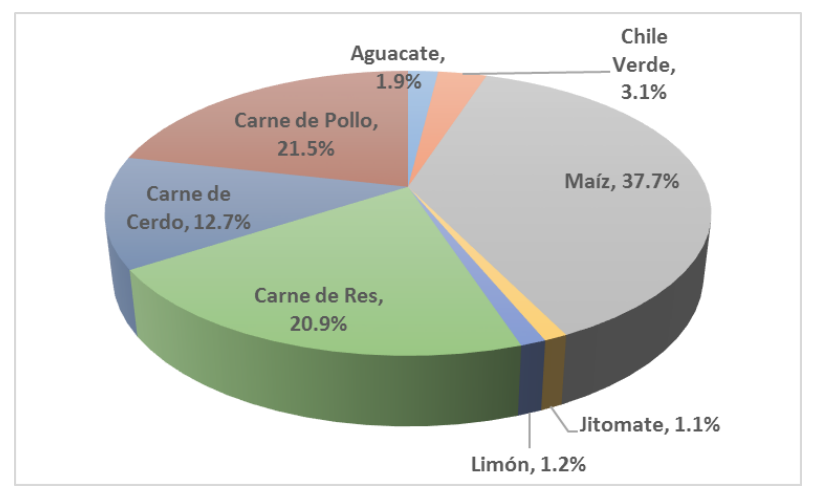

Graphic 1 Distribution of Average Spending for each Good

Source: Own elaboration with data from SIAP 2016 


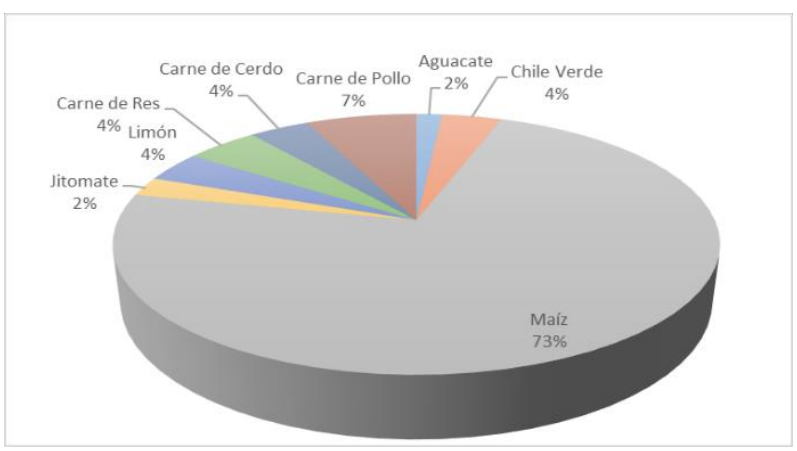

Graphic 2 Distribution of Average Consumption in Tons for each Good

Source: Own elaboration with data from SIAP 2016

The results of the procedure in SAS to be able to generate the regression estimators for the almost ideal demand model (AIDS) using the Stone Price Index, meet the following additivity, homogeneity and symmetry conditions:

$$
\sum_{i=1}^{n} \alpha_{i}=1, \quad \sum_{i=1}^{n} \gamma_{i j}=\sum_{i=1}^{n} \beta_{i}=0, \quad \sum_{j=1}^{m} \gamma_{i j}=0, \quad \gamma_{i j}=\gamma_{j i}
$$

Because the result obtained from $\mathrm{R} 2$ is very low, we proceeded to validate the model based on the analysis of individual estimators using the t-Student estimator. The regression estimators to build the model, obtained through the SYSLIN / SUR functions of SAS, are summarized in Table 3. The main results are for Chile, Corn and Tomato.

From the above results we have that only the origin estimator for avocado is significant with respect to the origin estimators, as is the budget estimator. Therefore, the obtained model is valid for the analysis of this product, the objective of this work. As for the other estimators, most of those related to avocado have statistical relevance.

\begin{tabular}{|l|r|r|r|r|}
\hline \multicolumn{1}{|l|}{ Estimator } & \multicolumn{1}{c}{ Value } & \multicolumn{1}{r|}{ Variance } & \multicolumn{1}{r|}{ T-Student } & Probability \\
\hline A1 & 0.1587 & 0.0414 & 3.83 & 0.0002 \\
\hline A2 & 0.3373 & 0.0525 & 6.42 & $<.0001$ \\
\hline A3 & -3.476 & 0.0846 & -41.1 & $<.0001$ \\
\hline A4 & 0.1249 & 0.0247 & 5.05 & $<.0001$ \\
\hline A5 & 0.0752 & 0.021 & 6.26 & $<.0001$ \\
\hline A6 & 1.558 & 0.0322 & 48.35 & $<.0001$ \\
\hline A7 & 0.8333724 & 0.0238 & 35.09 & $<.0001$ \\
\hline B1 & -0.00955 & 0.0028 & -3.42 & 0.0009 \\
\hline B2 & -0.018011 & 0.00359 & -5.05 & $<.0001$ \\
\hline B3 & 0.27864 & 0.00526 & 52.95 & $<.0001$ \\
\hline B4 & -0.00841 & 0.00165 & -5.09 & $<.0001$ \\
\hline B5 & -0.00414 & 0.000754 & -5.49 & $<.0001$ \\
\hline B6 & -0.09575 & 0.00151 & -63.48 & $<.0001$ \\
\hline B7 & -0.05278 & 0.00116 & -45.32 & $<.0001$ \\
\hline Y11 & 0.008584 & 0.00497 & 1.73 & 0.0864 \\
\hline Y12 & 0.000204 & 0.00407 & 0.05 & 0.9602 \\
\hline Y13 & -0.00283 & 0.00696 & -0.41 & 0.6846 \\
\hline Y14 & -0.00642 & 0.00238 & -2.7 & 0.008 \\
\hline Y15 & 0.004204 & 0.00132 & 3.19 & 0.0018 \\
\hline Y16 & 0.006501 & 0.00279 & 2.33 & 0.0215 \\
\hline Y17 & -0.00954 & 0.0022 & -4.34 & $<.0001$ \\
\hline Y22 & 0.021266 & 0.00675 & 3.15 & 0.0021 \\
\hline Y23 & 0.003319 & 0.0089 & 0.37 & 0.7097 \\
\hline Y24 & 0.004529 & 0.00271 & 1.67 & 0.0974 \\
\hline Y25 & -0.00006 & 0.00136 & -0.04 & 0.9658 \\
\hline Y26 & 0.003755 & 0.00279 & 1.35 & 1804 \\
\hline Y27 & -0.01404 & 0.00215 & -6.54 & $<.0001$ \\
\hline Y33 & 0.141754 & 0.023 & 6.16 & $<.0001$ \\
\hline Y34 & -0.00847 & 0.00495 & -1.71 & 0.0897 \\
\hline Y35 & -0.00858 & 0.00323 & -2.66 & 0.0089 \\
\hline Y36 & -0.01077 & 0.0117 & -0.92 & 0.3581 \\
\hline Y37 & -0.03318 & 0.00831 & -3.99 & $<.0001$ \\
\hline Y44 & 0.00398 & 0.00235 & 1.7 & 0.0924 \\
\hline Y45 & 0.000445 & 0.000972 & 0.46 & 0.6475 \\
\hline Y46 & 0.004927 & 0.00206 & 2.4 & 0.018 \\
\hline Y47 & 0.002851 & 0.00162 & 1.76 & 0.0816 \\
\hline Y55 & 0.005777 & 0.000958 & 6.03 & $<.0001$ \\
\hline Y56 & -0.00171 & 0.00173 & -0.99 & 0.3247 \\
\hline Y57 & 0.002337 & 0.00135 & 1.73 & 0.0869 \\
\hline
\end{tabular}

Table 2 List of Estimators of the AIDS Model and their tStudent values

Source: Own elaboration with data from SIAP 2017

In Table 3, the estimators of the AIDS model are grouped, in addition to checking the restrictions presented for their validation. Based on the fact that the AIDS model for the basic basket of eight basic products that are: Avocado, Lemon, Corn, Green Chile, Tomato, Beef, Pork and Chicken, which are an essential part of the daily diet of the population Mexicana proceeded to calculate the Hicksian, Marshallian and Expenditure / Income elasticities, based on the average proportion of expenditure assigned to them.

The elasticities obtained are summarized in a grouped manner in Table 5, in order to perform a more agile and visual analysis, to qualify each of the elasticities obtained. Once the elasticities were obtained, the results were classified, to define what type of products they are, summarizing the classification in Table 5. 
The main observation that results from seeing the classifications of the Hicksian elasticities is that all the products considered within the basic basket have an inelastic demand, which means that an increase in the budget generates in proportion a lower relative response towards consumption. of these products.

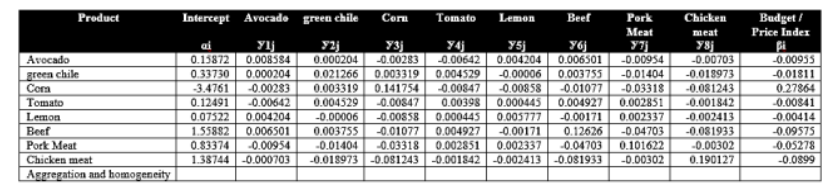

Table 3 Results of the estimators with validations of the assumptions of the AIDS model

Source: Own elaboration with data from SIAP 2017

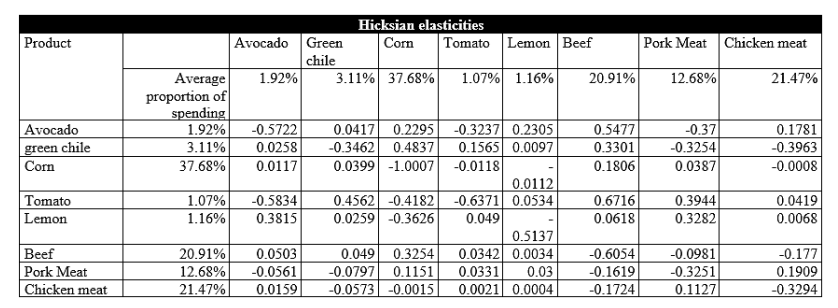

Table 4 Calculation of Hicksian Elasticities of the AIDS Model

Source: Own elaboration with data from SIAP 2017

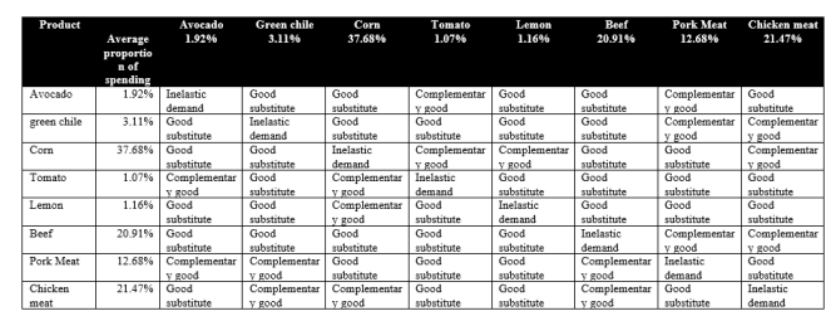

Table 5 Qualification of the Marshallian Elasticities of the AIDS model

Source: Own elaboration with data from SIAP 2017

The main observation that results from seeing the classifications of the Hicksian elasticities is that all the products considered within the basic basket have an inelastic demand, which means that an increase in the budget generates in proportion a lower relative response towards consumption. of these products.

Also highlighting that the consumption of avocado can be substituted for green chili, corn, lemon or beef and chicken, with only tomatoes and pork being their supplements, which has a certain coincidence with the current behavior of diet consumption. current nutritional status of the Mexican population, being also the second most substitutable product of the analyzed basket, just after the lemon.
Lemon is the product of the basic basket analyzed with the highest propensity to be substituted, since only corn complements it, while the other products are its substitutes. In second place, the products with the highest propensity to be substituted are the tomato, green chili and beef, together with avocado. Corn and pork and chicken are complementary products, since four out of seven products substitute them and three out of seven complement them.

From the expenditure elasticities of demand of the basic basket, we observe that all products are normal, except corn, indicating that if the budget is increased in the same way, the increase in demand for these is reflected, however in the case of corn, this is classified as luxury or giffen, the above can be assumed to have a double component of increase, since part of the consumption of corn in Mexico is for animal consumption, for meat production, and the other is for produce tortillas for direct consumption, as an essential part of the nutritional diet of the Mexican population.

This can be seen in Table 6, where the elasticities and their classification according to their value can be observed.

\begin{tabular}{|l|r|l|}
\multicolumn{1}{|c}{ Product } & $\begin{array}{r}\text { Spending } \\
\text { Elasticity }\end{array}$ & Type of Property \\
\hline Avocado & 0.5027 & Normal Goods \\
\hline Green chile & 0.4168 & Normal Goods \\
\hline Corn & 1.7394 & $\begin{array}{l}\text { Superior or luxury } \\
\text { good }\end{array}$ \\
\hline Tomato & 0.2106 & Normal Goods \\
\hline Lemon & 0.6432 & Normal Goods \\
\hline Beef & 0.5422 & Normal Goods \\
\hline Pork Meat & 0.5836 & Normal Goods \\
\hline Chicken meat & 0.5814 & Normal Goods \\
\hline
\end{tabular}

Table 6 Expenditure elasticities and classifications of goods

Source: Own elaboration with data from SIAP 2015

Avocado, having a budget elasticity of 0.5027 , remains a normal good, since an increase of $1 \%$ in the budget will only generate an increase in consumption of about $0.5 \%$.

On the other hand, the results for the Marshallian elasticities are summarized in Table 8, also a result of the AIDS analysis. In the same way, the elasticities were classified, which are summarized in Table 9. 
From the previous results we can see that both the Hicksian and Marshallian elasticities tell us that avocado complements the same two products (Tomato and Pork) and he is substituted by the others. However, under the Marshallian analysis we find that corn and chicken meat are products that complement almost all the products of the basic basket evaluated, which is very consistent with the reality of the Mexican diet.

On the other hand, lemon is substitutable for all other products, which at the time when lemon prices rose, practices of this nature were confirmed, substituting its consumption for other products from both the analyzed basket and others such as sour orange. . In this case, the tomato is the second product with the highest possibility of being substituted by one of the five six of the basic basket analyzed and only complements corn and avocado, the above may be a result of the drastic price variation that it suffers this product throughout the year, and throughout the years. Green chili and beef are products of intermediate propensity to be substituted as three out of seven products are substitutes and four out of seven are complementary.

From the above discussion it can be seen that both the Hicksian and Marshallian elasticities obtained under the almost ideal demand model for a basic basket of eight products, which includes avocado consumption, reveal that avocado has an inelastic national demand and that It is also a complementary product of tomato and pork; and in turn, a substitute product for corn, green chili, lemon and beef and chicken.

The foregoing helps us to infer the following: In the announced change to the increase in the minimum wage from $\$ 73.04$ to $\$$ 80.04, which represents $9.6 \%$, an increase in avocado consumption of only $5.5 \%$ would be expected. With which if this crop benefited. However, in the case of price elasticity, it can help us to infer the behavior that could have two political events of great interest, which are the change of government of the United States, with which the price elasticity of demand tells us the next:
- If there were any political change that would put a tariff barrier on this product, the supply to Mexico would be very high, thus generating an oversupply and lowering its prices, thus generating only an increase in the quantity demanded of barely $0.57 \%$ for every $1 \%$ of decrease in the price, therefore we could not absorb the sufficient quantity and the price would fall to very low levels, promoting in less quantity the consumption of substitute goods that are corn, green chili, lemon and beef and chicken.

- On the other hand, an increase in the exchange rate would make it more attractive to send the product abroad, generating scarcity and increasing prices for national consumption, generating or discouraging avocado consumption by $0.57 \%$ for every $1 \%$ increase in price, promoting the consumption of substitute goods that are corn, green chili, lemon, and beef and chicken.

\section{Conclusions}

The AIDS model obtained meets the conditions of additivity, homogeneity and symmetry. Avocado has inelastic national demand with an average expenditure of $1.92 \%$ of the budget assigned to a proposed basic basket made up of corn, green chili, tomato, lemon, beef, pork and chicken.

Avocado has a normal national spending demand with an elasticity of 0.5027 . Both the Hicksian and Marshallian elasticities obtained indicate that avocado is a good that complements the same two products (Tomato and Pork) and is substituted for the others.

It is inferred that the application of tariff barriers promotes avocado consumption by lowering the price, while an increase in the price of the dollar increases the price and decreases national consumption. The increase in the minimum wage may increase the expectation of an increase in avocado consumption, however it would not be elastic or unitary. 


\section{References}

Arellano, M. 2015. Consumo, pobreza y bienestar. Mesa Redonda en torno a la obra científica del Premio Nobel en Economía 2015, Angus Deanton. Fundación Ramón Areces. España. 22p. Disponible en: http://www.cemfi.es/ arellano/deaton-areces2015-tr.pdf [acceso en 15.05.19]

Deaton, A. y J. Muellbauer. 1999. Economics and consumer behavior. Ed. Cambridge. 450 p.

Fernández, S. 2007. Comportamiento del Consumidor y Estimaciones de demanda de alimentos. Universidad Nacional de Mar del Plata. Argentina. 69 p. Disponible en: http://nulan.mdp.edu.ar/1384/1/01223.pdf [acceso en 16.11.18]

Financiera Nacional de Desarrollo Agropecuario, Rural, Forestal y Pesquero. 2014. Panorama de Aguacate. Disponible en: $\mathrm{http} / / / \mathrm{www}$.financierarural.gob.mx/informacion sectorrural/Panoramas/Ficha\%20Aguacate.pdf [acceso en 14.11.18]

Gómez Gómez, Alma 2018. Estrategias de los Productores de Carne de Cerdo Mexicanos en el Mercado Japonés. Revista de Administración y Finanzas 2018. Disponible en http://www.ecorfan.org/bolivia/researchjournals /Administracion_y_Finanzas/vol5num17/Revist a_de\%20_Administraci\%C3\%B3n_y_Finanzas _V5_N17_2.pdf

González, A. 2013. UN SISTEMA DE DEMANDA CASI IDEAL (AIDS) APLICADO A CINCO GRANOS EN MÈXICO, 1980-2012. Tesis. Universidad Autónoma Chapingo. México. 115 p.

Kido-Cruz, A. y M.T. Kido-Cruz. S/f. Estimación de un Modelo de Demanda Casi Ideal para Determinar Cambios en la Estructura de Consumo de Carnes en los Estados Unidos de América. Revista CIMEXUS. Clasificación JEL: B23, C52. Disponible en: https://cimexus.umich.mx/index.php/cim1/articl e/view/151 [acceso en 16.01.19]
Miguel Ángel Martínez-Damián, M. A., J. S. Mora-Flores y R. Téllez-Delgado. 2016. DEMANDA POR CARNE DE PAVO: EFECTO PRECIO O EFECTO GASTO. Tropical and Subtropical Agroecosystems, 19 (2016): 139 - $144 . \quad$ Disponible: http://www.revista.ccba.uady.mx/ojs/index.php/ TSA/article/view/2127/1016 [acceso en 20.11.18] 